\title{
STUDY OF FRAUD TENDENCY: THE ROLE OF UNETHICAL BEHAVIORS AS MEDIATION
}

\author{
Siti Hamidah ${ }^{\mathrm{a}}$ \\ Reskino ${ }^{b}$ \\ ${ }^{a, b}$ Accounting Department, Faculty of Economics and Business, Syarif Hidayatullah State \\ Islamic University Jakarta \\ Email: siti.hamidah16@mhs.uinjkt.ac.id ${ }^{a} ; \underline{\text { reskino@uinjkt.ac.id }}^{b}$
}

\section{ARTICLE HISTORY}

Received:

12 January 2021

Revised

8 April 2021

Accepted:

31 May 2021

Online available:

30 June 2021

Keywords:

Conformity Compensation, Fraud Tendency,

Implementation of GCG Practice, Islamic Banking,

Islamic Insurance.

*Correspondence:

Name:

Siti Hamidah

Email:

siti.hamidah16@mhs.uinjkt.ac.id

\begin{abstract}
Islamic banking and Islamic insurance are institutions that are trusted by the public that play an important role in the economy that should uphold Islamic values. But in fact, there are still many cases of fraud that occur in Islamic banking and Islamic insurance. This study aims to examine the determinant factor fraud tendency with the role of unethical behavior as mediation. The sample used is the financial staff of Islamic banking and Islamic insurance in DKI Jakarta as many as 118 respondents. The data analysis method used in this research is Partial Least Square (PLSSEM). The results of this study indicate that the implementation of good corporate governance (GCG) practice has a significant effect on unethical behavior, but conformity compensation does not have a significant effect on unethical behavior. Conformity compensation, implementation of GCG practice, and unethical behavior has a significant effect on the fraud tendency. Furthermore, the implementation of GCG practice has a significant effect on fraud tendency through unethical behavior, but conformity compensation has no significant effect on fraud tendency through unethical behavior.
\end{abstract}

\section{INTRODUCTION}

Based on data from the Report to The Nations (RTTN) 2020 Global Study on Occupational Fraud and Abuse reported by the Association of Certified Fraud Examiners (ACFE), in 2018-2019 there were 2,504 cases of fraud from 125 countries, of which 198 cases came from countries in the Asia-region Pacific and Indonesia became the country with the highest number of cases of fraud in the Asia Pacific, namely 36 cases. In second place is China with 33 cases of fraud. Australia ranks third with 29 cases of fraud. Then, the Philippines and Malaysia with 24 and 19 cases of fraud, respectively. 


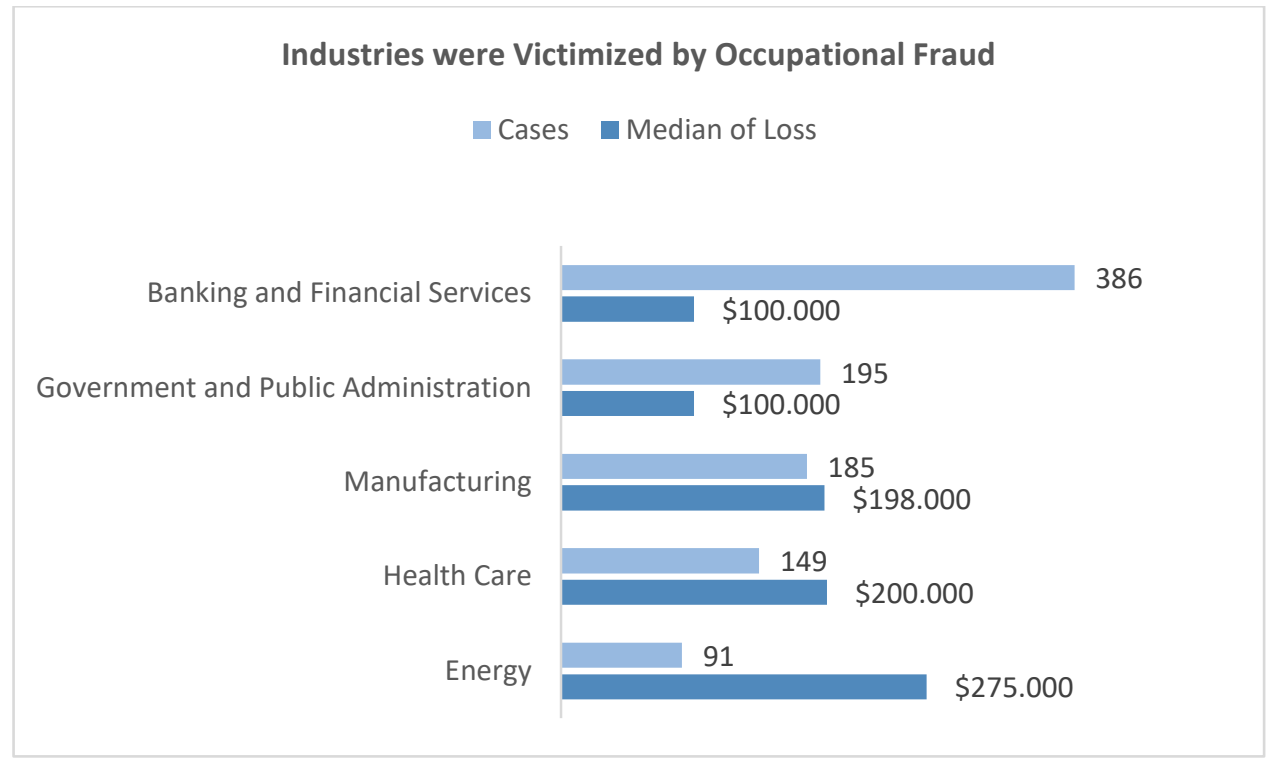

Source: (ACFE, 2020)

Figure 1. Industries were Victimized by Occupational Fraud

Furthermore, ACFE (2020) also states that banking and financial is the industry with the highest number of cases of fraud, which is 386 cases with an average loss of up to $\$ 100,000$.

In early 2020, the financial industry in Indonesia was shocked by the case of PT Asuransi Jiwasraya, which failed to pay a policy claim worth Rp12.4 trillion (Abdillah, 2020). The Audit Board of The Republic of Indonesia (BPK RI) explained that errors in managing investments were the main factor causing Jiwasraya to default (Ulya, 2020). This is considered as an activity that leads to practices fraudulent that not only involve the directors but also parties outside the company. The total financial assets in-stock instruments amounting to Rp5.7 trillion, only five percent was invested in companies with good performance, while the rest was invested in companies with poor performance (Friana, 2020).

On the other hand, the Islamic insurance industry is still able to grow when the Jiwasraya default case emerges. The Indonesian Sharia Insurance Association (AASI) recorded the Islamic insurance business as reflected in the contribution (premium) growing 8.69\% from Rp15.36 trillion in 2018 to Rp16.7 trillion in 2019 (Winarto, 2020). However, the National Committee for Sharia Economics and Finance (2020) stated that three challenges must be related to the Islamic insurance industry, one of which is Islamic financial inclusion which declined due to the spread of insurance fraud cases, especially that happened to Jiwasraya. Indirectly, the fraud that occurs will affect public confidence in the Islamic insurance industry.

Islamic insurance does not escape financial polemics. As happened to PT Asuransi Syariah Mubarakah (ASM) which was declared bankrupt on September 6, 2016, after the bankruptcy application submitted by the OJK was received by the panel of judges at the Central Jakarta Commercial Court. The Assembly considered ASM could not maintain financial health (solvency) in running its business as 
regulated in Law Number 2 of 1998 concerning Insurance, after its business license was revoked by the Indonesian Ministry of Finance on December 28, 2012 (Dewi, 2018).

The Islamic banking sector in Indonesia is also inseparable from several fraud cases. As happened to Bank Syariah Mandiri, which lost Rp50 billion due to embezzlement and document falsification committed by its employees (Kartika, 2015). Then in 2018, there were allegations of disbursement of financing worth Rp1.1 trillion by Bank Syariah Mandiri with indications of use for personal interests (Fauzie \& Agustiyanti, 2018). There were also cases in 2019, in which the former Managing Director of Panin Dubai Syariah Bank committed embezzlement, fraud, and money laundering related to Islamic financing facilities received by customers (Saleh, 2019). Based on the Report of the Implementation of Corporate Governance in each Islamic bank during 2015-2019, the data related to the number of internal fraud are presented as follows:

Table 1

Internal Fraud in Islamic Banking 2015-2019

\begin{tabular}{lccccc}
\hline & 2015 & 2016 & 2017 & 2018 & 2019 \\
\hline Bank Muamalat Indonesia & 2 & 83 & 35 & 21 & 26 \\
Bank Syariah Mandiri & 8 & 25 & 25 & 14 & 10 \\
BRI Syariah & 4 & 6 & 6 & 8 & 10 \\
BNI Syariah & 3 & 6 & 0 & 9 & 9 \\
Bank BCA Syariah & 0 & 0 & 0 & 0 & 0 \\
Bank Mega Syariah & 1 & 4 & 3 & 3 & 1 \\
Bank NET Indonesia Syariah & 0 & 0 & 1 & 0 & 0 \\
BTPN Syariah & 0 & 0 & 0 & 0 & 0 \\
Bank Syariah Bukopin & 0 & 0 & 1 & 0 & 2 \\
Bank Panin Dubai Syariah & 4 & 2 & 3 & 1 & 0 \\
Bank Victoria Syariah & 7 & 4 & 1 & 1 & 1 \\
\hline
\end{tabular}

Source: Report of the Implementation of GCG (2015-2019)

With some examples of the cases and the data above, it shows that there is no guarantee that Islamic banking can avoid fraud. According to Rahmayani and Rahmawaty (2017), each organization has its risks related to fraud.

Even though the Indonesian public's awareness of the growth of the halal lifestyle is a new opportunity for the growth of the halal industry, especially Islamic banking (Jamil, 2020). The latest statistics released by the OJK show that during 20162019, 14 Sharia Commercial Banks (BUS) in Indonesia recorded an average growth of 11\% (Rustam, 2020).

According to Fauwzi (2011), the number of cases of irregularities that occur in Indonesia is due to one factor of unethical behavior. Unethical behavior usually arises because individuals feel dissatisfied or disappointed with the compensation provided by the company and the weakness of supervision which can open up the flexibility to take unethical actions. However, according to Rae and Subramaniam (2008), 
unethical behavior can be suppressed by existing regulations so that it will not affect the fraud tendency.

Another factor that influences a person to practice the fraud tendency is the pressure that arises from inappropriate compensation. Compensation mismatch will encourage employees to commit fraud to meet the needs and pressures they feel due to inappropriate compensation (Ryan \& Ridwan, 2017). However, the research results of Nurlaeliyah and Anisykurlillah (2017) explain that conformity compensation does not affect the fraud tendency. High or low compensation will not affect someone in doing the fraud tendency.

Apart from the factors previously described, the implementation of good corporate governance (GCG) is also closely related to the fraud tendency. According to Ramadhany et al. (2017), capital market management bodies in many countries have succeeded in preventing fraudulent practices by implementing good corporate governance in public companies.

This study is a development of the research by Nurlaeliyah and Anisykurlillah (2017). The novelty in this study is the use of implementation of GCG practice as an independent variable. The effect of implementation of GCG practice on the fraud tendency through unethical behavior has not been widely studied. In addition, the application of research objects is also different, that is financial staffs who work in Islamic banking and Islamic insurance.

Based on the description above, this study aims to analyze the factors that influence the fraud tendency with the role of unethical behavior as mediation. Researchers hope that with this research, Islamic banking and Islamic insurance can improve their ability to prevent and minimize fraud tendency by increasing various internal factors such as conformity compensation and implementation of GCG practice.

\section{LITERATURE REVIEW}

\section{Fraud Pentagon Theory}

This theory was developed by Horwath (2011). In addition to pressure, opportunity, and rationalization, the fraud pentagon theory develops risk factor capability into competence and adds one risk factor, namely arrogance as a factor that can influence someone to commit fraud. Competence is an extension of the opportunity element which includes the ability of individuals to override internal control, develop concealment strategies, and socially control the situation for personal gain (Horwath, 2011). Arrogance is a behavior of superiority or greed owned by fraudsters who feel that internal controls, policies, and company regulations do not apply to them (Horwath, 2011). This arrogance arises from the belief that he is capable of cheating without fear of being caught up in sanctions (Cahyaningtyas \& Achsin, 2015). 


\section{Islamic Banking}

Islamic banks are financial institutions that function to facilitate economic mechanisms in the real sector through business activities, namely investing, buying, and selling, and others based on Islamic principles, namely the rules of agreements based on Islamic law (AI-Quran and As-Sunah) between banks and other parties to deposit funds or finance business activities or other activities declared by sharia values, both macro, and micro. The macro values in question are justice, maslahah, the zakat system, free from interest (riba), free from nonproductive speculative activities such as gambling (maysir), free from unclear and doubtful things (gharar), free from things damaged or illegitimate things (batil), and the use of money as a medium of exchange. Meanwhile, micro values are noble traits exemplified by the Prophet Muhammad, namely shiddiq, amanah, tabligh, and fathanah (Ascarya, 2008).

\section{Islamic Insurance}

Fatwa Dewan Syariah Nasional Number 21/DSN-MUI/X/2001 concerning General Guidelines for Islamic Insurance states that what is meant by Islamic insurance is an effort to protect and help each other between some people or parties through investments in the form of assets and/or tabarru provide a pattern of return to face certain risks through an agreement (engagement) by sharia. The contracts (engagement) that are by sharia are contracts that do not contain gharar (fraud), maysir (gambling), riba, zulm (persecution), rishwah (bribes), as well as haram and immoral goods (Manan, 2012).

\section{The Effect of Conformity Compensation on Unethical Behavior}

Research results of Nurlaeliyah and Anisykurlillah (2017); Shintadevi (2015) explain that conformity compensation has a significant negative effect on unethical behavior. This research indicates that the higher the employee feels conformity compensation, the lower the ethical behavior performed by the employee. However, the results of the research by Natalia (2018) show opposite results, that there is no influence between conformity compensation and unethical behavior. This indicates that low or high compensation does not affect a person's behavior. Based on the contradiction above, it is assumed that:

$H_{1}$ : Conformity compensation has a significant effect on unethical behavior.

\section{The Effect of Implementation of GCG Practice on Unethical Behavior}

Fauzan (2014) explains that behavior in the management of BOS funds is influenced by the implementation of good corporate governance practices. By 
implementing practices of good corporate governance, it will reduce unethical behavior. The research results of Carcello (2009) also states that corporate governance is one of the tools that can protect companies from unethical behavior and practices. Turnbull (2009) also explains that law, regulation, and corporate governance will reduce unethical practices. Based on the explanation above, it is assumed:

$\mathrm{H}_{2}$ : Implementation of GCG practices has a significant effect on unethical behavior.

\section{The Effect of Conformity Compensation on Fraud Tendency}

The research results of Putri and Irwandi (2017); Shintadevi (2015) show that conformity compensation has a significant negative effect on the fraud tendency. Providing improper compensation will make employees have an incentive to commit fraud to meet the needs and pressures they feel due to inappropriate compensation. Meanwhile, the results of research by Natalia (2018); Nurlaeliyah and Anisykurlillah (2017) explain that high or low compensation will not affect a person in committing a fraud tendency. Based on the contradiction above, it is assumed that:

$\mathrm{H}_{3}$ : Conformity compensation has a significant effect on the fraud tendency.

\section{The Effect of Implementation of GCG Practice on Fraud Tendency}

The results study of Ansori (2017) shows that the implementation of good corporate governance practices has a significant negative effect on the fraud tendency. The implementation of good corporate governance has an effect on the focus of company management in a clearer division of duties, powers, responsibilities, and supervision, to minimize the fraud tendency. The study of Halbouni et al. (2016) also explains that corporate governance has a moderate role in preventing and detecting fraud tendency. This is supported by the research results of Ismail and Abdelmoniem (2013) which shows that weak corporate governance, such as low disclosure levels and CEO duality, increases the fraud tendency. Based on the explanation above, it is assumed that:

$\mathrm{H}_{4}$ : Implementation of GCG practice has a significant effect on fraud tendency.

\section{The Effect of Unethical Behavior on Fraud Tendency}

Research results from Natalia (2018); Nurlaeliyah and Anisykurlillah (2017); Shintadevi (2015) explain that unethical behavior has a positive effect on fraud tendency, meaning that when the unethical behavior is high, the level of fraud tendency would also be high. However, this is not supported by the results of research by Meiryani et al. (2019) which explained that unethical behavior did not affect the fraud tendency. In a more ethical environment, employees will tend to 
follow company rules, so that unethical behavior can be suppressed by existing regulations so that it will not affect the fraud tendency (Rae \& Subramaniam, 2008). Based on the contradiction above, it is assumed that:

$H_{5}$ : Unethical behavior has a significant effect on the fraud tendency.

\section{The Effect of Conformity Compensation on Fraud Tendency through Unethical Behavior}

Research results from Nurlaeliyah and Anisykurlillah (2017); Shintadevi (2015) explain that conformity compensation affects fraud tendency through unethical behavior. The provision of appropriate compensation is expected to make individuals feel fulfilled so that they will not take actions that are detrimental to the organization including committing accounting fraud. However, this is not in line with the results of the research by Natalia (2018) which explains that conformity compensation does not significantly determine the fraud tendency through unethical behavior. Conformity compensation has not been able to prevent unethical behavior which will have an impact on the fraud tendency. Based on the contradiction above, it is assumed that:

$H_{6}$ : Conformity compensation has a significant effect on fraud tendency through unethical behavior.

\section{The Effect of Implementation of GCG Practice on Fraud Tendency through Unethical Behavior}

Research results from Carcello (2009); Fauzan (2014); Turnbull (2009) state that practices of good corporate governance can reduce unethical behavior. Meanwhile, research results from Ansori (2017); Halbouni et al. (2016); Ismail and Abdelmoniem (2013) show that the implementation of good corporate governance practices has a significant negative effect on the fraud tendency. On the other hand, the results of research by Nurlaeliyah and Anisykurlillah (2017); Shintadevi (2015) explain that unethical behavior has a positive effect on fraud tendency. It means that the higher the unethical behavior, the level of fraud tendency also tend to be high. However, this is not supported by the results of research by Meiryani et al. (2019) which explained that unethical behavior did not affect the fraud tendency. Based on the explanation above, it is assumed that:

$H_{7}$ : Implementation of GCG practice has a significant effect on fraud tendency through unethical behavior. 


\section{RESEARCH METHODS}

\section{Population and Sample}

This study used the causality methods with primary data to analyze the cause-and-effect relationship used to explain the effect of the conformity compensation and implementation of GCG practice on the tendency fraud with unethical behavior as a mediator. The population taken in this study is the financial staffs who work in Islamic banking and Islamic insurance, while the sample in this study is the financial staffs who work in Islamic banking and Islamic insurance in the DKI Jakarta area. This study chose this sample because fraud in Islamic banking and Islamic insurance is quite high based on the data previously describe and DKI Jakarta is one of the regions in Indonesia that has a large number of Islamic banks and Islamic insurance. In this study, the sampling method used was purposive sampling, with the following qualifications: (1) financial staff who works in Islamic banking and Islamic insurance in DKI Jakarta; and (2) financial staff who have at least one year of work experience, because they are deemed to have sufficient experience to understand the internal company. After distributing questionnaires online, a sample of 118 respondents was obtained.

\section{Operational Definition and Measurement of Variable}

Conformity compensation is an individual's perception of the entire remuneration received in the form of salaries, wages, bonuses, and other benefits as something that is in line with the implementation of work in the organization (Arsad, 2018). In this study, conformity compensation is measured using indicators developed by Wilopo (2006) and adjusted to the research topic using four indicators, namely salary and wages, intensive, allowances, and facilities.

Good corporate governance is a process or structure used by an entity to provide added value to the entity in a sustainable manner in the long term for shareholders while still paying attention to the interests of other stakeholders based on the prevailing laws and norms (Daniri, 2005). In this study, implementation of GCG practice is measured using indicators developed by Gusnardi (2011) and adjusted to the research topic using five indicators, namely transparency, accountability, responsibility, professional, and fairness.

According to Griffin and Ronald (2006), unethical behavior is behavior that is not by generally accepted social norms, in connection with actions that are not useful or harmful. In this study, unethical behavior was measured using indicators developed by Adelin and Fauzihardani (2013); Fitri et al. (2016) adjusted to the research topic using four indicators, namely abuses position, abuses organizational resources, abuses power, and no action.

Fraud tendency is the desire to take any action to gain profit dishonestly so that it can harm other parties such as covering up the truth, fraud, manipulation which can be in the form of misstatement of financial reports, corruption, and assets 
miss appropriation (Hasanudin \& Pangayow, 2016). In this study, fraud tendency was measured using indicators developed by Ansori (2017); Aranta (2013); Karyono (2013), and adjusted to the research topic using three indicators, namely tendency to commit corruption, tendency to misuse assets, and the tendency to commit fraudulent financial statements.

\section{Data Analysis}

The test method in this study consisted: (1) descriptive statistics; (2) test the outer model (convergent validity, discriminant validity, and reliability); (3) test the inner model (R-Square, Q-Square, and hypothesis testing); and (4) test the intervening effect.

\section{RESULT AND ANALYSIS}

\section{Test Results of Descriptive Statistics}

The results of descriptive statistical tests show that the standard deviation of conformity compensation is 4.373 , implementation of GCG practice 5.733 , while the unethical behavior and fraud tendency are 3.481 and 4.042. Furthermore, the results of the descriptive statistical test show the average value of each variable, namely conformity compensation 43.89; implementation of GCG practice 56.53; unethical behavior 46.67; and fraud tendency 73.08. This illustrates that the standard deviation of each variable has a lower value when compared to the average value of each variable, thus indicating that the quality of the data in this study is good. Based on the results of the descriptive statistical test, it can be concluded that the average respondent's answer to the variable conformity compensation, implementation of GCG practice, unethical behavior, and fraud tendency is agreed.

\section{Test Results of Measurement Model (Outer Model)}

Convergent validity of the indicator's reflective measurement model is assessed based on the correlation between the item score or component score estimated by the software SmartPLS. The individual reflective measure is said to be correlated if it is higher than 0.70 with the measured construct. However, for research in the early stages of developing a measurement scale the value of loading 0.50 to 0.60 is considered sufficient (Ghozali, 2015). In this study, the limit loading factor used was 0.50 .

Based on the results of data processing shown in Figure 2, three indicators have a value loading factor of less than 0.50 , including CC_3, CC_6, and GCG_11. Therefore, these indicators must be excluded from the model because they do not have a value loading factor adequate.

Table 2 shows that each variable has obtained composite reliability above 0.70 so it can be said that all constructs are reliable. Moreover, each variable has also 
obtained a Cronbach alpha above 0.60 so it can be concluded that the responses from each respondent have a good level of consistency.

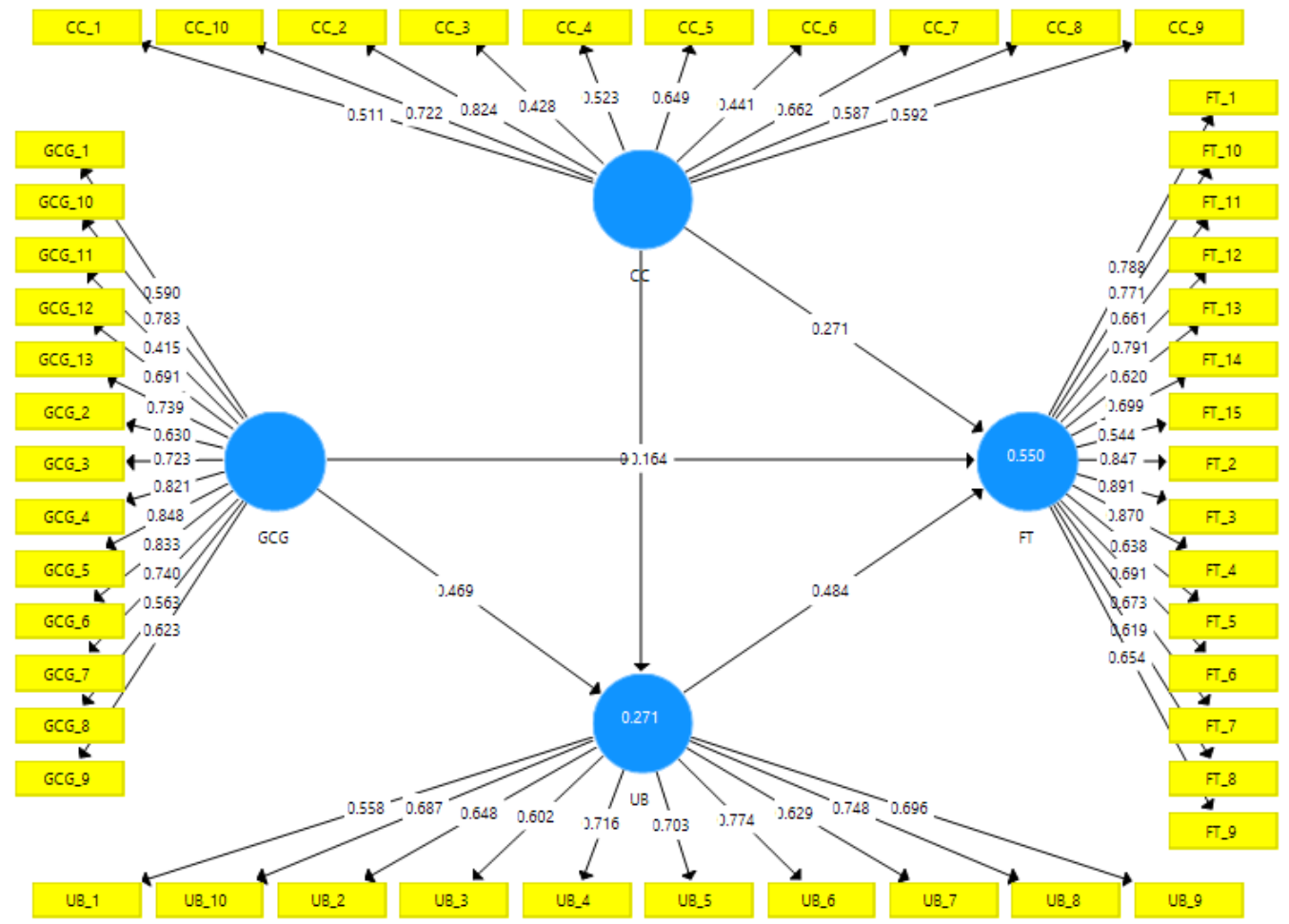

Figure 2. Path Diagram Accompanied by Values Loading Factor Source: Processed Data (2020)

Table 2

Composite Reliability and Cronbach Alpha

\begin{tabular}{lcc}
\hline & Composite Reliability & Cronbach Alpha \\
\hline Conformity Compensation & 0.846 & 0.805 \\
Implementation of GCG Practice & 0.928 & 0.915 \\
Unethical Behavior & 0.895 & 0.868 \\
Fraud Tendency & 0.942 & 0.933 \\
\hline
\end{tabular}

Source: Processed Data (2020)

\section{Results of the Structural Model Test (Inner Model)}

Testing of the inner model or structural model is carried out to see the relationship between constructs based on substantive theory. The structural model was evaluated using the R-Square for the dependent construct, the Stone-Geisser square test ( $Q$-Square) for predictive relevance, and the t-test and significance of the structural path parameter coefficients.

Table 3

Value of R-Square

\begin{tabular}{lc}
\multicolumn{2}{c}{ Value of R-Square } \\
\hline & R-Square \\
\hline Unethical Behavior & 0.269 \\
Fraud Tendency & 0.552 \\
\hline
\end{tabular}

Source: Processed Data (2020) 
Table 3 shows the value of R-Square for variable unethical behavior obtained at 0.269 and variable fraud tendency obtained 0.552 . These results indicate that the independent variables in this study are simultaneously able to explain the variable unethical behavior by $26.9 \%$ and the remaining $73.1 \%$ are explained by other variables that are not hypothesized in the model. Then, the variable fraud tendency explained simultaneously by the independent variable by $55.2 \%$, and the remaining $44.8 \%$ was explained by other variables that were not hypothesized in the model. The R-Square value for the variable unethical behavior is in the weak to moderate category, while the variable fraud tendency in the moderate to strong category.

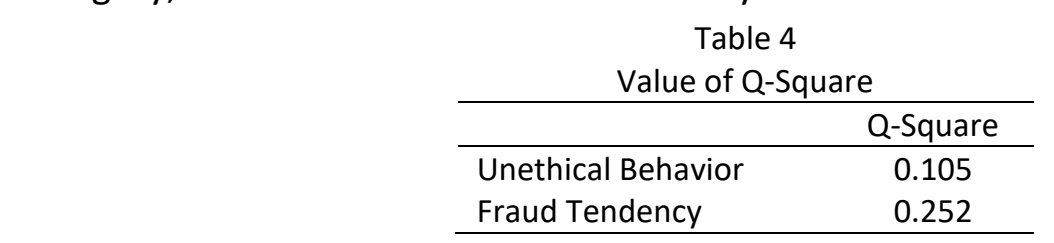

Source: Processed Data (2020)

Table 4 shows the values Q-Square for the variables unethical behavior obtained for 0.105 and variables fraud tendency obtained 0.252 . These results indicate that the variable unethical behavior has a value predictive relevance which is in the weak to moderate category, while the variable fraud tendency in the moderate to strong category. Based on this description, it can be concluded that the independent variable has a predictive relevance with the dependent variable in this research model.

\section{Hypothesis Test Results Hypothesis}

The bootstrapping method is used to test the hypothesis in this study. Hypothesis testing is done by comparing the t-statistic value with the t-table. The $t$ table in this study is 1.981 which is obtained from the df value of 116 , namely the number of samples is reduced by two (118-2) and $\alpha$ is 0.05 (two-tailed). The limit of the hypothesis is accepted or rejected is \pm 1.981 . Therefore, if the t-statistic value is in the range of $-1,981$ and 1,981, then the hypothesis will be rejected or the null hypothesis $\left(\mathrm{H}_{0}\right)$ is accepted.

Table 5

\begin{tabular}{lllccccc}
\multicolumn{8}{c}{ Path Coefficients (Mean, STDEV, T-Value) } \\
\hline Original & $\begin{array}{c}\text { Sample } \\
\text { Mean (M) }\end{array}$ & $\begin{array}{c}\text { Standard Deviation } \\
\text { (StDev) }\end{array}$ & $\begin{array}{c}\text { T-Statistic } \\
\text { (IO/stdev) }\end{array}$ & P Value \\
\hline CC & $\rightarrow$ & UB & 0.109 & 0.131 & 0.090 & 1.217 & 0.224 \\
GCG & $\rightarrow$ & UB & 0.454 & 0.456 & 0.078 & 5.798 & 0.000 \\
CC & $\rightarrow$ & FT & 0.269 & 0.301 & 0.085 & 3.158 & 0.002 \\
GCG & $\rightarrow$ & FT & 0.172 & 0.159 & 0.078 & 2.213 & 0.027 \\
UB & $\rightarrow$ & FT & 0.478 & 0.476 & 0.075 & 6.406 & 0.000 \\
\hline
\end{tabular}

Source: Processed Data (2020) 
Table 5 explains that the effect of conformity compensation on unethical behavior is 0.109 and not significant at $0.05(1.217<1.981)$. The effect of the implementation of GCG practice on unethical behavior is 0.454 and significant at 0.05 (5.798 $>1.981)$. The effect of conformity compensation on fraud tendency is 0.269 and significant at 0.05 (3.158>1.981). The effect of the implementation of GCG practice on fraud tendency was 0.172 and significant at 0.05 (2.213>1.981). The effect of unethical behavior on fraud tendency was 0.478 and significant at 0.05 (6.406>1.981).

\section{Test Results of Intervening Effect}

The first step is to test the indirect effect of variable $X$ to variable $Y$ through variable $\mathrm{M}$, with the formula: $\mathrm{Sat}=\mathrm{Vb}^{2} \mathrm{Sa}^{2}+\mathrm{a}^{2} \mathrm{Sb}^{2}+\mathrm{Sa}^{2} \mathrm{Sb}^{2}$. The second step is to test to determine the significance of the indirect effect by calculating the t-statistic of the coefficient $a b$ with the formula: $t=a b /$ Sab.

Table 6

Results of the Intervening Effect

\begin{tabular}{lllllc}
\multicolumn{8}{c}{ Results of the Intervening Effect } \\
\hline \multicolumn{1}{l}{} & & & & T-Statistic \\
\hline CC & $\rightarrow$ & UB & $\rightarrow$ & FT & 1.182 \\
GCG & $\rightarrow$ & UB & $\rightarrow$ & FT & 4.224
\end{tabular}

Source: Processed Data (2020)

Table 6 shows the results of the test through the Sobel test that there is an effect of intervening variable unethical behavior on the indirect relationship between the variable implementation of GCG practice and the fraud tendency because it has a $\mathrm{t}$-statistic greater than t-table which is 1.981 . Meanwhile, in the indirect relationship between the variable conformity compensation and the fraud tendency, there was no intervening effect on the variable unethical behavior because the t-statistic was smaller than the t-table, namely 1.981.

\section{The Effect of Conformity Compensation on Unethical Behavior}

The results of the tests that have been done show a t-statistic value of 1.217. This value is smaller than the t-table 1.981 , so the first hypothesis $\left(\mathrm{Ha}_{1}\right)$ is rejected. This shows that the perception of the financial staff of Islamic banking and Islamic insurance regarding conformity compensation has not been able to prevent unethical behavior. The provision of appropriate compensation does not minimize abuse of power, abuse of position, abuse of company resources, and no action that is detrimental to the company. This is because no compensation system clearly describes rights and obligations, measures of achievement or failure to perform, as well as rewards and penalties. As reflected in the responses of respondents who stated that no system regulates performance allowances and incentives that are by their work results, so that it cannot prevent employees from unethical behavior, even though the compensation received is as expected. The results of this study are in line with the research of Natalia (2018) which explains that conformity compensation 
does not affect unethical behavior. However, the results of this study are not supported by research by Nurlaeliyah and Anisykurlillah (2017); Shintadevi (2015) which state that conformity compensation has a significant effect on unethical behavior.

\section{The Effect of Implementation of GCG Practice on Unethical Behavior}

The results of the tests that have been done show a t-statistic value of 5.798. This value is greater than the t-table 1.981 so that the second hypothesis $\left(\mathrm{Ha}_{2}\right)$ is accepted. This shows that the implementation of good corporate governance practices in Islamic banking and Islamic insurance can keep its financial staff away from unethical behavior. In this study, the implementation of good corporate governance practices can encourage employees to behave ethically and avoid deviant behavior by the company's code of ethics. The code of conduct requires employees to carry out ethical practices on behalf of the company. If these principles are rooted in the company culture, all employees will try to understand and comply with them, so that unethical behavior can be minimized. Based on the responses of the respondents, the implementation of good corporate governance practices will increase the sense of responsibility, professionalism, and employee perceptions of justice, so that unethical behavior can be avoided. The results of this study are consistent with the research of Carcello (2009); Fauzan (2014); Turnbull (2009) which states that the implementation of GCG practice can reduce unethical behavior.

\section{The Effect of Conformity Compensation on Fraud Tendency}

The results of the tests that have been done show a t-statistic value of 3.158. This value is greater than the t-table 1.981 , so the third hypothesis $\left(\mathrm{Ha}_{3}\right)$ is accepted. This shows that the perception of the financial staff of Islamic banking and Islamic insurance regarding conformity compensation can minimize the fraud tendency. Conformity compensation can provide satisfaction and motivation to employees at work, such as receiving appropriate and timely salaries, as well as the availability of facilities that can support the performance of employees, thus encouraging them to give the best for the institution where they work, one of which is by avoiding the fraud tendency. This is by the statement of Erickson et al. (2006) who reported that the compensation structure can be used as an alternative to reduce the level of the tendency to fraud, to increase performance, or awareness to achieve performance. The results of this study are in line with the research of Putri and Irwandi (2017); Shintadevi (2015) which show that conformity compensation has a significant effect on the fraud tendency. However, the results of this study are not supported by research by Natalia (2018); Nurlaeliyah and Anisykurlillah (2017) which explain that conformity compensation does not affect the fraud tendency.

Published by University of Airlangga.

This is an open access article under the CC BY license (https://creativecommons.org/licenses/by-nc-sa/4.0/) 


\section{The Effect of Implementation of GCG Practice on Fraud Tendency}

The results of the tests that have been done show a t-statistic value of 2.213 . This value is greater than the t-table 1.981, so the fourth hypothesis $\left(\mathrm{Ha}_{4}\right)$ is accepted. This shows that the implementation of good corporate governance practices in Islamic banking and Islamic insurance can minimize the fraud tendency. To reduce the risk of the fraud tendency, companies are responsible for implementing a control program, one of which is through the implementation of good corporate governance. There is a tendency for fraud to occur if the control process has not been properly implemented. However, if the control system is running well, a controlled environment will be created so that the tendency to cheat can be avoided. Based on the responses of respondents, the implementation of good corporate governance will increase transparency and accountability in financial management, thereby reducing the potential for fraud tendency. The results of this study are from the research of Ansori (2017); Halbouni et al. (2016); Ismail and Abdelmoniem (2013) which state that the implementation of GCG practice has a significant effect on the fraud tendency.

\section{The Influence of Unethical Behavior on Fraud Tendency}

The results of the tests that have been done show a t-statistic value of 6.406 . This value is greater than the t-table 1.981 so that the fifth hypothesis $\left(\mathrm{Ha}_{5}\right)$ is accepted. This shows that the fraud tendency that occurs in Islamic banking and Islamic insurance is influenced by unethical behavior. Based on the responses of the respondents, the behavior of abusing position, power, and organizational resources can lead a person to commit fraud tendency. Besides, no action or doing nothing when an individual is engaging in unethical behavior will encourage that individual to dare to commit fraud tendency. There are several general rationalizations used by actors to justify unethical behavior, including pretending to behave unethically, excusing yourself by saying it is in the interests of the organization, assume that no one will know if he commits unethical behavior, and expecting that someone will support and protect if the act is detected at a later date. Thus, two important factors cause a person to behave unethically so that they tend to cheat, namely the possibility of being detected and the size of the punishment. The results of this study are in line with the research of Natalia (2018); Nurlaeliyah and Anisykurlillah (2017); Shintadevi (2015) which states that unethical behavior has a significant effect on fraud tendency. However, the results of this study are not supported by research by Meiryani et al. (2019); Rae and Subramaniam (2008) which show that unethical behavior does not affect the fraud tendency.

\section{The Effect of Conformity Compensation on Fraud Tendency through Unethical Behavior}


The results of the tests that have been done show a significant t-statistic value at 0.05 , namely $1.182<1.981$, so that the sixth hypothesis $\left(\mathrm{Ha}_{6}\right)$ is rejected. This shows that the perception of the financial staff of Islamic banking and Islamic insurance regarding conformity compensation has not been able to prevent unethical behavior so that the fraud tendency has not been able to be significantly minimized. The absence of a compensation system that is clearly described has resulted in unethical behavior resulting in a fraud tendency, even though the compensation received is as expected. Even though it does not have a significant effect, conformity compensation is still needed. Providing appropriate compensation can provide satisfaction and motivation to employees at work, thus encouraging them to give the best for the agencies where they work. With the provision of appropriate compensation, it is hoped that unethical actions and the tendency of fraud can be avoided. The results of this study are from the research of Natalia (2018) which explains that conformity compensation does not significantly determine the fraud tendency through unethical behavior. However, the results of this study are not in line with the research of Nurlaeliyah and Anisykurlillah (2017); Shintadevi (2015) which state that conformity compensation has a significant effect on fraud tendency through unethical behavior.

\section{The Effect of Implementation of GCG Practice on Fraud Tendency through Unethical Behavior}

The results of the tests that have been carried out show a significant t-statistic value at 0.05 , namely $4.224>1.981$ so that the seventh hypothesis $\left(\mathrm{Ha}_{7}\right)$ is accepted. This shows that the implementation of good corporate governance practices in Islamic banking and Islamic insurance can prevent its financial staff from unethical behavior to minimize the fraud tendency. When the principles of good corporate governance are implemented properly, unethical behavior can be prevented, so that the chance of fraud tendency can be minimized. The implementation of good corporate governance practices can encourage employees to behave ethically and avoid deviant behavior by the company's code of ethics. The code of conduct requires employees to carry out ethical practices on behalf of the company. If this principle is rooted in the corporate culture, it will increase transparency and accountability in financial management and minimize the potential for fraud. The results of this study are supported by research by Carcello (2009); Fauzan (2014); Turnbull (2009) which states that practices good corporate governance can reduce unethical behavior. Then, the results of this study are from the research of Nurlaeliyah and Anisykurlillah (2017); Shintadevi (2015) which show that unethical behavior has a significant effect on the fraud tendency. Therefore, the implementation of GCG practice has a significant effect on the fraud tendency through unethical behavior.

Published by University of Airlangga.

This is an open access article under the CC BY license (https://creativecommons.org/licenses/by-nc-sa/4.0/) 


\section{CONCLUSION}

This study aims to examine the factors that influence the fraud tendency with the role of unethical behavior as mediation. The results of this study conclude that the implementation of GCG practice has a significant effect on unethical behavior, while conformity compensation has no significant effect on unethical behavior. Then, conformity compensation, implementation of GCG practice, and unethical behavior have a significant effect on the fraud tendency. Furthermore, implementation of GCG practice has a significant effect on fraud tendency through unethical behavior, while conformity compensation has no significant effect on fraud tendency through unethical behavior.

This study has several limitations, including: (1) the instrument in this study was limited to the use of a questionnaire, which only measured personal perceptions; and (2) the population in this study only focused on the financial staff of Islamic banking and Islamic insurance, without seeing other elements that were indirectly involved in unethical behavior and fraud tendency.

Based on the limitations of the research above, here are some suggestions that can be considered for future research, including: (1) using interview techniques and identification of other data as material for consideration in assessing the objectivity of respondent responses; (2) take a larger sample to generalize the research results and add other variables such as locus of control, leadership style, motivation, and integrity.

The results of this study are expected to be a reference in the academic field as empirical evidence and literature in studying theories related to unethical behavior and fraud tendency. The results of this study are also expected to provide an overview and information to practitioners and companies about the perception of conformity compensation and the implementation of good corporate governance practices as an effort to prevent unethical behavior so that the fraud tendency can be avoided. Then, the results of this study are expected to be a consideration for regulators in making policies to encourage the implementation of good corporate governance to minimize the potential for unethical behavior that will reduce the fraud tendency.

\section{ACKNOWLEDGEMENT}

This research was supported by UIN Syarif Hidayatullah Jakarta. We are thankful to our colleagues who provided expertise that greatly assisted the research. We are also grateful to Institute of Indonesia Chartered Accountants Educator Accountant Compartment and Forum of Riau College Accounting Lecturer for holding the $1^{\text {st }}$ Konra Riau Seminar and National Conference (Riau Accounting Research Conference) who moderated this paper and improved the manuscript significantly. 


\section{REFERENCES}

Abdillah. (2020). Kasus Jiwasraya dan Asabri. LIPUTAN6. https://www.liputan6.com/news/read/4155702/kasus-jiwasraya-dan-asabri

ACFE. (2020). Report to The Nations Global Study on Occupational Fraud and Abuse.

Adelin, V., \& Fauzihardani, E. (2013). Pengaruh Pengendalian Internal, Ketaaatan pada Aturan Akuntansi dan Kecenderungan Kecurangan Terhadap Perilaku Tidak Etis. Wahana Riset Akuntansi, 1(2), 259-276. http://ejournal.unp.ac.id/index.php/wra/article/view/2641

Ansori, A. F. (2017). Pengaruh Implementasi Good University Governance, Keefektifan Sistem Pengendalian Internal dan Ketaatan Aturan Akuntansi Terhadap Kecenderungan Fraud Pada PTKIN-BLU [Universitas Lampung]. http://digilib.unila.ac.id/29622/

Aranta, P. Z. (2013). Pengaruh Moralitas Aparat dan Asimetri Informasi Terhadap Kecenderungan Kecurangan Akuntansi (Studi Empiris Pemerintah Kota Sawahlunto). Jurnal Akuntansi, 1(1), 1-26. http://ejournal.unp.ac.id/students/index.php/akt/article/view/116

Arsad, I. K. (2018). Analisis Faktor-Faktor yang Mempengaruhi Terjadinya Kecurangan Akuntansi (Fraud) di Pemerintah Kota Jayapura. Jurnal Akuntansi \& Keuangan Daerah, 13(2), 1-12.

http://ejournal.akuntansiuncen.ac.id/index.php/JurnalAkuntansiUncen/article/v iew/59

Ascarya, A. (2008). Akad dan Produk Bank Syariah. Raja Grafindo Persada.

Cahyaningtyas, R. I., \& Achsin, M. (2015). Studi Fenomenologi Kecurangan Mahasiswa dalam Pelaporan Pertanggungjawaban Dana Kegiatan Mahasiswa: Sebuah Realita dan Pengakuan. Jurnal IImiah Mahasiswa FEB Universitas Brawijaya, 3(2). https://jimfeb.ub.ac.id/index.php/jimfeb/article/view/2252

Carcello, J. V. (2009). Governance and the Common Good. Journal of Business Ethics, 89, 11-18. https://doi.org/10.1007/s10551-008-9904-z

Daniri, A. (2005). Good Corporate Governance Konsep dan Penerapannya dalam Konteks Indonesia. Ray Indonesia.

Dewi, H. K. (2018). Polemik Aset dalam Kepailitan Asuransi Syariah Mubarakah. Kontan.Co.Id.

Erickson, M., Hanlon, M., \& Maydew, E. L. (2006). Is There a Link between Executive Compensation and Accounting Fraud? Journal of Accounting Research, 44(1), 113-143. https://www.jstor.org/stable/3542319?seq=1

Fauwzi, M. G. H. (2011). Analisis Pengaruh Keefektifan Pengendalian Internal, Persepsi Kesesuaian Kompensasi, Moralitas Manajemen Terhadap Perilaku Tidak Etis dan Kecenderungan Kecurangan Akuntansi [Universitas Diponegoro]. http://eprints.undip.ac.id/28669/

Fauzan, F. (2014). Pengaruh Penerapan Good Corporate Governance Terhadap Perilaku Etis Dalam Pengelolaan Dana Bantuan Operasional Sekolah. Jurnal Ekonomi MODERNISASI, 10(3), 158-169. https://doi.org/10.21067/jem.v10i3.776

Fauzie, Y. Y., \& Agustiyanti, A. (2018). Bank Syariah Mandiri Diduga Beri Pembiayaan Fiktif Rp1,1 T. CNN Indonesia. 
Fitri, Y., Nurazlina, N., \& A, A. A. (2016). Pengaruh Keefektifan Sistem Pengendalian Internal, Ketaatan Aturan Akuntansi, Sistem Asimetri Informasi, dan Moralitas Individu Terhadap Kecenderungan Kecurangan Akuntansi dengan Perilaku Tidak Etis sebagai Variabel Intervening. Jurnal Online Mahasiswa Fakultas Ekonomi, 3(1), 505-519.

https://jom.unri.ac.id/index.php/JOMFEKON/article/view/10448/10106

Friana, H. (2020). Betapa Rumitnya Mengurai Kasus Jiwasraya. Tirto.

https://tirto.id/betapa-rumitnya-mengurai-kasus-jiwasraya-erAC

Ghozali, I. (2015). Konsep, Teknik, dan Aplikasi Menggunakan Program Smart PLS 3.0 (2nd ed.). Salemba Empat, Universitas Diponegoro.

Griffin, R. W., \& Ronald, J. E. (2006). Bisnis (Alih Bahas). Erlangga.

Gusnardi, G. (2011). Pengaruh Peran Komite Audit, Pengendalian Internal, Audit Internal, dan Pelaksanaan Tata Kelola Perusahaan terhadap Pencegahan Kecurangan. EKUITAS (Jurnal Ekonomi Dan Keuangan), 15(1), 130-146. https://doi.org/10.24034/j25485024.y2011.v15.i1.196

Halbouni, S. S., Obeid, N., \& Garbou, A. (2016). Corporate Governance and Information Technology in Fraud Prevention and Detection: Evidence from The UAE. Managerial Auditing Journal, 31(6), 589-628.

https://doi.org/10.1108/MAJ-02-2015-1163

Hasanudin, A. I., \& Pangayow, B. J. C. (2016). Analisis Faktor-Faktor yang Berpengaruh Terhadap Kecenderungan Kecurangan Akuntansi dan Perilaku Tidak Etis (Studi Kasus pada SKPD di Kabupaten Keerom). Jurnal Akuntansi \& Keuangan Daerah, 11(1), 1-12. https://ejournal.uncen.ac.id/index.php/JAKED/article/view/1408 Horwath, C. (2011). Article on Fraud.

Ismail, T. H., \& Abdelmoniem, Z. (2013). Stock Option Fraud Prevention in Islamic Country: Does Corporate Governance Matter? Journal of Financial Reporting and Accounting, 11(1), 4-28. https://doi.org/10.1108/JFRA-03-2013-0013

Jamil, E. R. N. (2020). Berpotensi Besar, Perbankan Syariah Perlu Didukung. Ayocirebon.Com. https://m.ayocirebon.com/read/2020/02/13/4527/berpotensi-besarperbankan-syariah-perlu-didukung

Kartika, U. (2015). Orang Dalam "Bermain", Bank Syariah Mandiri Dibobol Rp 50 Miliar. Kompas.Com.

https://megapolitan.kompas.com/read/2015/02/02/18582981/Orang.Dalam.Be rmain.Bank.Syariah.Mandiri.Dibobol.Rp.50.Miliar

Karyono. (2013). Forensic Fraud. CV Andi Offset.

Manan, A. (2012). Hukum Ekonomi Syariah dalam Prespektif Kewenangan Peradilan Agama. Kencana Pernada Media Group.

Meiryani, M., Fenando, F., Susanto, A., \& Warganegara, D. L. (2019). The Effect of Accounting Information Systems Performance and Unthetic Behavior on Accounting Fraud. International Journal of Recent Technology and Engineering (IJRTE), 8(3), 2718-2725. https://doi.org/10.35940/ijrte.C4966.098319

Natalia, E. Y. (2018). Efektivitas Pengendalian Intern dan Kesesuaian Kompensasi Terhadap Kecenderungan Kecurangan Akuntansi dengan Perilaku Tidak Etis Sebagai Variabel Intervening pada Perusahaan di Kota Batam. Jurnal Akuntansi Barelang, 3(1), 32-42. http://113.212.163.133/index.php/jab/article/view/713 National Committee for Sharia Economics and Finance. (2020). Insight: Buletin 
Ekonomi Syariah, Optimisme Asuransi Syariah Capai Pertumbuhan Produktif 2020. KNEKS.

Nurlaeliyah, S., \& Anisykurlillah, I. (2017). Analysis of Factors Affecting The Tendency of Accounting Fraud with An Ethical Behavior As Intervening Variable. Accounting Analysis Journal, 6(2), 299-312. https://doi.org/10.15294/aaj.v6i2.16892

Putri, P. A. A., \& Irwandi, S. A. (2017). The Determinants of Accounting Fraud Tendency. The Indonesian Accounting Review, 6(1), 99. https://doi.org/10.14414/tiar.v6i1.857

Rae, K., \& Subramaniam, N. (2008). Quality of Internal Control Procedures: Antecedents and Moderating Effect on Organisational Justice and Employee Fraud. Managerial Auditing Journal, 23(2), 104-124. https://doi.org/10.1108/02686900810839820

Rahmayani, R., \& Rahmawaty, R. (2017). Pengaruh Islamic Corporate Governance dan Internal Control Terhadap Indikasi Terjadinya Fraud Pada Bank Umum Syariah di Indonesia. Jurnal IImiah Mahasiswa Ekonomi Akuntansi (JIMEKA), 2(3), 18-38. http://www.jim.unsyiah.ac.id/EKA/article/view/4395

Ramadhany, I., Indrawati, N., \& L, A. A. (2017). Pengaruh Sistem Pengendalian Intern, Asimetri Informasi, Kesesuaian Kompensasi, dan Implementasi Good Corporate Governance Terhadap Kecenderungan Kecurangan Akuntansi. Jurnal Online Mahasiswa Fakultas Ekonomi, 4(1), 1253-1267. https://jom.unri.ac.id/index.php/JOMFEKON/article/view/12730

Rustam, B. R. (2020). Milestone Strategis Perbankan Syariah 2020. Investor.Id. https://investor.id/opinion/milestone-strategis-perbankan-syariah-2020

Ryan, M., \& Ibrahim, R. (2017). Pengaruh Kesesuaian Kompensasi, Penerapan Sistem Informasi Akuntansi, dan Efektivitas Pengendalian Internal Terhadap Kecurangan Akuntansi Studi pada Bank Perkreditan Rakyat (BPR) di Kota Banda Aceh. Jurnal IImiah Mahasiswa Ekonomi Akuntansi (JIMEKA), 2(4), 136-145. http://jim.unsyiah.ac.id/EKA/article/view/5221

Saleh, T. (2019). Terseret Kasus SNP Finance, Ini Evaluasi Bank Panin Dubai. CNBC Indonesia. https://www.cnbcindonesia.com/market/20190418151812-1767589/terseret-kasus-snp-finance-ini-evaluasi-bank-panin-dubai

Shintadevi, P. F. (2015). Pengaruh Keefektifan Pengendalian Internal, Ketaatan Aturan Akuntansi, dan Kesesuaian Kompensasi Terhadap Kecenderungan Kecurangan Akuntansi dengan Perilaku Tidak Etis sebagai Variabel Intervening. NOMINAL: Barometer Riset Akuntansi Dan Manajemen, 4(2), 111-126. https://doi.org/10.21831/nominal.v4i2.8003

Turnbull, S. (2009). Why "Best" Corporate Governance Practices are Unethical and Less Competitive. In L. Hartman \& J. Desjardins (Eds.), Business Ethics: DecisionMaking for Personal Integrity \& Social Responsibility. McGraw-Hill. https://ssrn.com/abstract=1260047

Ulya, F. N. (2020). Simak, Ini Kronologi Lengkap Kasus Jiwasraya Versi BPK. Kompas.Com. https://money.kompas.com/read/2020/01/09/063000926/simakini-kronologi-lengkap-kasus-jiwasraya-versi-bpk?page=all.

Wilopo, W. (2006). Analisis Faktor-Faktor yang Berpengaruh Terhadap Kecenderungan Kecurangan Akuntansi: Studi Pada Perusahaan Publik dan Badan 
Jurnal Ekonomi dan Bisnis Islam, Vol. 7, No.1, January-June 2021

Usaha Milik Negera Di Indonesia. The Indonesian Journal of Accounting Research, 9(3), 21-69. https://doi.org/10.33312/ijar.163

Winarto, Y. (2020). Meski Ada Kasus Jiwasraya, Premi Asuransi Syariah Tumbuh 8,69\% yoy di 2019. Kontan.Co.Id. https://keuangan.kontan.co.id/news/meskiada-kasus-jiwasraya-premi-asuransi-syariah-tumbuh-869-yoy-di-2019?page=2 . 